\title{
Biochemical and Utralmicroscopic Evaluation of Myofibril Proteins and Collagen during Ageing in Broiler Chicken PSE (Pale, Sof, Exudative) Meat
}

Denis Fabrício Marchi ${ }^{1 *}$

https://orcid.org/0000-0002-8234-4696

Flávia Maria Beteto ${ }^{2}$

https://orcid.org/0000-0003-0997-5317

Gleice Rocha dos Santos Almeida ${ }^{2}$

https://orcid.org/0000-0003-0079-1626

Adriana Lourenço Soares ${ }^{2}$

https://orcid.org/0000-0002-8515-2796

Francisco Javier Hernandez-Blazquez ${ }^{3}$

https://orcid.org/0000-0001-7388-4458

\section{Elza louko Ida ${ }^{2}$}

https://orcid.org/0000-0002-5128-6366

\section{Massami Shimokomaki²}

https://orcid.org/0000-0002-8751-0710

${ }^{1}$ Federal Institute of Parana - Campus Londrina, Londrina, Parana, Brazil, ${ }^{2}$ State University of Londrina, Londrina, Parana, Brazil; ${ }^{3}$ São Paulo University, São Paulo, São Paulo, Brazil;

Received: 2018.03.05; Accepted: 2019.05.19.

*Correspondence: denis.marchi@ifpr.edu.br, Tel.: +55-43-3878-6300

\section{HIGHLIGHTS}

- Cathepsins $B+L$ and $L$ activities have a prolonged action in PSE fillets.

- PSE meat presents accelerated protein degradation in relation to the control fillets. 
Abstract: The aim of this work was to study the myofibril proteins and collagen fraction changes in broiler chickens PSE (pale, soft, exudative) meat during ageing and their relationship to meat quality. The results presented an increase of myofibril proteins and collagen solubility promoted by the enhanced proteases activities during storage. Ultramicroscopically, the PSE meat samples revealed intracellularly a sarcomere super contraction and lacunas within the $A$ and I bands while Z-lines appeared very dense and fragmented in comparison to normal samples. This observation was noticed already at $4 \mathrm{~h}$ storage while extracellularly collagen fibrils decreased visually within the endomysium only after $24 \mathrm{~h}$ of conditioning. These results influenced the quality as the PSE meat presented better functional properties at the first hours of conditioning before further proteins degradation by proteases. Thereafter, at the later ageing stage a further disintegration of the abnormal meat structure would affect the meat functional properties.

Keywords: Cooking loss; Tenderness; Collagen content; Myofibrillar Fragmentation Index.

\section{INTRODUCTION}

Meat tenderness is one of the most important factors to consumers. The development of this tenderness during ageing is dependent on the meat architecture, the integrity of the skeletal muscle cell, the activity of endogenous proteases such as calpains and cathepsins within the cell and the extracellular matrix proteins [1,2]. The development of tenderness in poultry is dependent also on the fast decrease in $\mathrm{pH}$ post mortem under warm carcass temperature developing PSE meat (pale, soft, exudative) leading to the denaturation of myofibril proteins impairing their functional properties [3]. There are controversies over the tenderness of PSE meat and its relationship to the proteases activity. We have previously reported that chicken PSE meat had lower shear force and higher myofibrillar fragmentation index attributing these results to the calpains enzymatic activities as the consequence of the surplus of $\mathrm{Ca}^{2+}$ within the muscle cell milieu promoted by PSE developmental conditions [3]. According to Claeys et al. [4], a fast decrease in $\mathrm{pH}$ values followed by an increase in the concentration of $\mathrm{Ca}^{2+}$ can result in a premature activation of calpains and subsequently this activity decreased by the calpains autolysis during post mortem conditions. In skeletal muscle, the calpain system consists of several proteases, and two types of them, $\mu$ - and $\mathrm{m}$-calpain and their inhibitor calpastatin, are thought to be involved in the proteolytic meat tenderization. Both $\mu$ - and m-calpains are calcium dependent and are composed of 80 and $28 \mathrm{kDa}$ subunits, and both suffer autolisys in the presence of $\mathrm{Ca}^{2+}$ [5]. Furthermore, several reports have shown that collagen properties such as fiber sizes, genetic types, total content and the presence of crosslinking mediated by lysyl oxidase are important for determining the contribution of this protein for meat texture [2,6]. There is evidence that post mortem changes occur within the connective tissue due to the action of lysosomal proteases (cathepsins), which act on the degradation of collagen during ageing [7]. Cathepsins are a group of enzymes comprised of both exo- and endo-peptidases [8]. Reports have indicated that cathepsins $B$ and $L$ activities at $8 \mathrm{~h}$ post mortem have been found positively correlated with tenderness in beef and can act on collagen molecules $[9,10]$. Cathepsins are located within the lysosomes and must be released in order to have access to myofibril and connective tissue proteins, thus providing meat tenderness [11]. However, low pH values and high carcass temperature can enhance the disruption of the lysosome membrane ${ }^{10}$, as it seems to happen in PSE meat [12-14]. Several studies have indicated that proteases activity may be associated with fast decrease in $\mathrm{pH}$ post mortem $[3,15,16]$, but the extent of these changes, as well as specifically the changes in PSE meat quality during ageing is unknown. Therefore, the aim of this present work was to study both myofibril proteins and collagen fraction biochemical and ultrastructural changes during ageing of broiler chicken PSE meat and its relationship to quality. 


\section{MATERIAL AND METHODS}

\section{Samples Preparation}

Breast meat (Pectoralis major m.) samples were obtained from 42-day old broilers from a commercial plant located in the South of Brazil. The animals were slaughtered according to the standard industrial practice and essentially consisted of electrical stunning, bleeding, defeathering, evisceration, water-cooling the carcass, deboning and refrigeration [3]. The length of time from slaughtering to samples collection was about 3 hours. Birds were handled in accordance with the principles and procedures outlined by the Londrina State University Animal Care and Use Ethical Committee.

\section{Biochemical and Physicochemical Parameters}

$\mathrm{pH}$ was measured 3 and 24 hours post mortem by inserting electrodes into the meat samples using a contact pH meter system (Testo 205), as reported in [17]. Thirty-six samples were classified as PSE meat $\left(\mathrm{pH}_{3 \mathrm{~h}} \leq 5.8\right)$ and thirty-six samples as control $\left(\mathrm{pH}_{3 \mathrm{~h}}>\right.$ 5.9). A Minolta CR400 colorimeter was used to evaluate the color $\left(L^{*}, a^{*}, b^{*}\right)$ of the posterior surface of intact skinless breast muscle at $24 \mathrm{~h}$ post mortem. The $\mathrm{L}^{*}, \mathrm{a}^{*}$ and $\mathrm{b}^{*}$ values were measured at three different sites on the same sample: the proximal extremity of muscle, the distal extremity of the muscle and the medial side half-way between the proximal and distal extremities [12].Samples were vacuum packed in plastic bags and aged for $0 \pm 1^{\circ} \mathrm{C}$ for 24 , 72 and $120 \mathrm{~h}$ post mortem (twelve fillets meat for ageing time), totaling 36 samples from each group (PSE and control meat). Samples were taken for Myofibrillar Fragmentation Index (MFI) determination, Cooking Loss, Shear Force Measurement, Total and Soluble Collagen content at 24,72 and $120 \mathrm{~h}$ post mortem.

\section{Myofibrillar Fragmentation Index (MFI)}

MFI was determined in triplicate as an indirect measurement of calpain activity, according to Culler et al. [18] as described in Wilhem et al. [3]. Two grams of muscle samples, free of external fat and visible connective tissue, were homogenized for $30 \mathrm{~s}$ in 10 $\mathrm{mL}$ of MFI buffer (100 mM KCl, $20 \mathrm{mM}$ potassium phosphate, $1 \mathrm{mM}$ EDTA, $1 \mathrm{mM} \mathrm{MgCl}_{2}$ and $1 \mathrm{mM} \mathrm{NaN}_{3}$ at pH 7.0). The homogenate was centrifuged at $10,000 \mathrm{rpm}$ for $15 \mathrm{~min}$ at $2{ }^{\circ} \mathrm{C}$, the supernatant discarded and the pellet resuspended in $10 \mathrm{~mL}$ of the MFI buffer and centrifuged at $10,000 \mathrm{rpm}$ for $15 \mathrm{~min}$ at $2^{\circ} \mathrm{C}$. The supernatant was discarded and the pellet suspended in $5 \mathrm{~mL}$ of the same MFI buffer. The myofibril suspension was poured through a filter paper to remove connective tissue, and then assayed for protein concentration using the Biuret method. Aliquots of the suspensions were diluted in the MFI buffer to a final protein concentration of $0.5 \mathrm{mg} / \mathrm{mL}$. The diluted protein suspension was poured into a cuvette and the absorbance at $540 \mathrm{~nm}$ was immediately measured with a spectrophotometer. The MFI was expressed as $A_{540 n m} \times 200$.

\section{Cooking Loss (CL)}

CL was measured according to Honikel [19]. Samples were packed in plastic bags and submitted to cooking in a water bath for 30 min until internal temperature reached $75^{\circ} \mathrm{C}$. CL was expressed as the weight difference before and after cooking.

\section{Shear Force (SF) Measurement}

The samples were the same as the CL analysis. Samples were cut into $1 \times 1 \times 2 \mathrm{~cm}(\mathrm{n}=$ 08 from each sample), and analyzed on a texturometer TATX-2i. The results were expressed in newton $(\mathrm{N})$.

\section{Cathepsin Activities}

Cathepsins $\mathrm{B}+\mathrm{L}, \mathrm{B}$, and $\mathrm{H}$ activities were determined in triplicate, according to Toldrá and Etherington [20]. Samples ( $\mathrm{n}=10$ per group) were collected at 4, 24, and $72 \mathrm{~h}$ post mortem, totaling 30 samples per group. Protease activity was measured using a spectrofluorometer at an excitation wavelength of $355 \mathrm{~nm}$ and an emission wavelength of 
$460 \mathrm{~nm}$. Results were expressed in fluorescence units (FU); $1 \mathrm{FU}$ corresponds to the amount of enzyme capable of hydrolyzing $1 \mu \mathrm{mol}$ of substrate in $1 \mathrm{~h}$ at $37^{\circ} \mathrm{C}$.

\section{Collagen Content}

The total collagen content in samples was determined in triplicate after $15 \mathrm{~h}$ of hydrolysis of $1.0 \mathrm{~g}$ of meat with $15 \mathrm{~mL} 6 \mathrm{M} \mathrm{HCl}$ at $105^{\circ} \mathrm{C}$, as reported by Woessner [20]. The hydrolysate was filtered and its $\mathrm{pH}$ adjusted between 6.0 and 7.0 with $33 \%(\mathrm{w} / \mathrm{v}) \mathrm{NaOH}$, and diluted with distilled water to $250 \mathrm{~mL}$. An aliquot of $2 \mathrm{~mL}$ of hydrolyzed sample and $1 \mathrm{~mL}$ of cloramine $T$ solution were mixed in a test tube and left for $20 \mathrm{~min}$ at room temperature and 1 $\mathrm{mL}$ of $3.15 \mathrm{M} \mathrm{HClO}_{4}$ was added and left for $5 \mathrm{~min}$ at room temperature. Then, $1 \mathrm{~mL}$ of 4-dimethyl-aminobenzaldehyde was added and solutions were shaken and heated at $60{ }^{\circ} \mathrm{C}$ for $20 \mathrm{~min}$. The samples were cooled down for $5 \mathrm{~min}$ in water tap and the absorbance measured at $560 \mathrm{~nm}$. The amount of hydroxyproline was determined from a standard curve. The Total Collagen content (TC) was calculated from hydroxyproline content using the coefficient 8.0 [20].

Soluble collagen (SC) was extracted in triplicate according to the modified method of Oliveira et al. [21]. Samples $(2.5 \mathrm{~g})$ were mixed for $1 \mathrm{~min}$ with $20 \mathrm{~mL}$ of deionized water and it was heated for $60 \mathrm{~min}$ at $80^{\circ} \mathrm{C}$. Samples were homogenized at 22,000 rpm in Ultra Turrax and centrifuged for $15 \mathrm{~min}$ at $4,000 \mathrm{rpm}$. Supernatant was filtered and $30 \mathrm{~mL}$ of $6 \mathrm{M} \mathrm{HCl}$ added for hydrolysis as described previously. Soluble collagen was evaluated as described for total collagen content.

\section{Histological Evaluation}

Histological evaluation by electron microscopy was performed as in Guarnieri et al. [22]. Samples ( $n=6$ from ageing time) after 3, 24, 72, and 120 hours post mortem were fixed in $2 \%$ glutaraldehyde in a $0.14 \mathrm{M}$ sodium cacodylate buffer at $\mathrm{pH} 7.4$, containing 0.18 $\mathrm{M}$ sucrose. After washing in phosphate buffer, the samples were post-fixed in $1 \%$ osmium tetroxide in phosphate buffer for $2 \mathrm{~h}$, followed by dehydration in acetone, and embedding in Araldite resin. Ultrathin sections $(50 \mathrm{~nm})$ were stained with saturated uranyl acetate in $50 \%$ ethanol and lead citrate for $1 \mathrm{~h}$. The sample ultrastructure was observed with a JEOL JEM-1010 scanning electron microscope.

\section{Statistical Analysis}

Statistical analysis was carried out using Statistic software, version 7.0. Student t-test was used to determine significant difference among two samples of PSE and control meat at the same storage time. Tukey's test was used to determine significant difference among storage periods of time for PSE or control meat samples. Pearson correlations coefficients were used for testing correlations between $\mathrm{pH}_{3 \mathrm{~h}}, \mathrm{pH}_{24 \mathrm{~h}}, \mathrm{~L}^{*}$ values, MFI, CL, SF, TC and SC.

\section{RESULTS}

\section{Physicochemical Parameters}

$\mathrm{pH}$ and $\mathrm{L}^{*}$ values were significantly different typical for control and PSE meats, as previously reported $[3,12,17,23]$. The $\mathrm{pH}$ values decreased gradually throughout the post mortem periods evaluated in the control group while in PSE meat samples there was a faster decrease $(p=0.27)$, due to the rapid glycolysis, consequently the meat was paler, showing higher $L^{*}$ and $b^{*}$ (yellowness) values typical of PSE meat (Table 1). The* value was higher for the control samples, showing higher red value (Table 1 ). 
Table 1 Means $( \pm S D)$ Comparison of physicochemical parameters between control and PSE (Pale, Soft, Exudative) broiler breast meat (Pectoralis major $\mathrm{m}$.) samples

\begin{tabular}{ccc}
\hline Groups & PSE $(\mathbf{n}=\mathbf{3 6})$ & Control $(\mathbf{n}=\mathbf{3 6})$ \\
\hline $\mathbf{p H}_{3 \mathrm{~h}}$ & $5.64^{\mathrm{b}, \mathrm{B}} \pm 0.051$ & $6.05^{\mathrm{a}, \mathrm{A}} \pm 0.053$ \\
$\mathbf{p H}_{24 \mathrm{~h}}$ & $5.67^{\mathrm{b}, \mathrm{A}} \pm 0.086$ & $5.98^{\mathrm{a}, \mathrm{B}} \pm 0.063$ \\
$\mathbf{L}^{*}$ & $60.21^{\mathrm{a}} \pm 1.279$ & $52.10^{\mathrm{b}} \pm 3.776$ \\
$\mathbf{a}^{*}$ & $0.19^{\mathrm{b}} \pm 0.485$ & $2.27^{\mathrm{a}} \pm 0.619$ \\
$\mathbf{b}^{*}$ & $6.46^{\mathrm{x}} \pm 2.195$ & $4.97^{\mathrm{y}} \pm 0.990$ \\
\hline
\end{tabular}

$\mathrm{pH}_{3 \mathrm{~h}}$ : $\mathrm{pH} 3$ hours post mortem; $\mathrm{pH}_{24 h}$ : $\mathrm{pH}_{24} 4$ hours post mortem; $\mathrm{L}^{*}$ : lightness; $\mathrm{a}^{*}$ : green-red component; $b^{*}$ : yellow-blue component.

a-b Means within each line with different superscripts are different $(p \leq 0.01)$.

$x-y$ Means within each line with different superscripts are significantly different $(p \leq 0.05)$.

$A-B$ Means within each column with different superscripts are different $(p \leq 0.01)$.

\pm Standard Deviation

\section{Cooking Loss (CL)}

There was no difference ( $p \geq 0.05$ ) between CL $24 \mathrm{~h}$ and CL $72 \mathrm{~h}$ in both groups (Table 2). However the CL $120 \mathrm{~h}$ post mortem value increased significantly ( $\mathrm{a} \leq 0.05$ ) approximately $9.2 \%$ for PSE.

The CL was higher for PSE fillets throughout the experiment. The highest CL value as observed in the PSE fillets samples was the consequence of rapid post mortem glycolysis leading to the denaturation of myofibrillar proteins that reduces their ability to retain water [17]. Therefore the CL amount was inversely proportional to the water holding capacity (WHC) [3]. The use of chicken PSE meat generates a product with low WHC and poorer cut when compared to the normal meat $[24,25]$. Thus, these biochemical events were expected to increase during ageing, especially in PSE meat due to the higher CL $120 \mathrm{~h}$ post mortem.

Table 2 Cooking loss of control and PSE (Pale, Soft, Exudative) meat samples of broiler breast stored at $0 \pm 1 \stackrel{\circ}{\circ}$ for 24,72 and 120 hours post mortem.

\section{Groups}

Cooking Loss (\%)

\begin{tabular}{cccc} 
& $\mathbf{2 4} \mathbf{h}(\mathbf{n}=\mathbf{1 2})$ & $\mathbf{7 2} \mathbf{h}(\mathbf{n}=\mathbf{1 2})$ & $\mathbf{1 2 0} \mathbf{h}(\mathbf{n}=\mathbf{1 2})$ \\
\hline PSE meat & $28.31^{\mathrm{b}, \mathrm{A}} \pm 2.32$ & $28.62^{\mathrm{b}, \mathrm{A}} \pm 1.16$ & $30.91^{\mathrm{a}, \mathrm{A}} \pm 2.62$ \\
Control meat & $23.85^{\mathrm{b}, \mathrm{B}} \pm 1.28$ & $25,46^{\mathrm{ab}, \mathrm{B}} \pm 1.43$ & $24,90^{\mathrm{a}, \mathrm{B}} \pm 1.19$ \\
\hline \multicolumn{4}{c}{$\mathrm{a} \pm 1$. significantly different in the same group $(\mathrm{p} \leq 0.05)}$. \\
& A-B: significantly different between groups $(\mathrm{p} \leq 0.05)$. \\
\multicolumn{4}{c}{ \pm Standard Deviation }
\end{tabular}

\section{Breast Meat Tenderness Measurement}

Table 3 shows the Shear Force (SF) values for PSE and control meat samples. It was observed that at $24 \mathrm{~h}$ post mortem, the SF showed lower values for PSE samples $(20.50 \mathrm{~N})$ comparing to control samples $(24.99 \mathrm{~N})(\mathrm{p} \leq 0.05)$ corroborating the results observed previously by Wilhelm et al. [3] stating that the lower SF value was due to the earlier activation of calpain in PSE meat samples in a pre rigor conditions. 
Table 3 Shear force of control and PSE (Pale, Soft, Exudative) meat samples of broiler breast stored at $0 \pm 1 \stackrel{\circ}{ } \mathrm{C}$ for 24,72 and 120 hours post mortem.

\begin{tabular}{cccc} 
Groups & \multicolumn{4}{c}{ Shear Force $(\mathbf{N})$} \\
& $\mathbf{2 4} \mathbf{h}(\mathbf{n}=\mathbf{1 2})$ & $\mathbf{7 2} \mathbf{h}(\mathbf{n}=\mathbf{1 2})$ & $\mathbf{1 2 0} \mathbf{h}(\mathbf{n}=\mathbf{1 2})$ \\
\hline PSE meat & $20.50^{\mathrm{b}, \mathrm{B}} \pm 3.31$ & $28.72^{\mathrm{b}, \mathrm{A}} \pm 11.54$ & $48.61^{\mathrm{a}, \mathrm{A}} \pm 14.07$ \\
Control meat & $24.99^{\mathrm{a}, \mathrm{A}} \pm 5.69$ & $24.31^{\mathrm{a}, \mathrm{A}} \pm 5.45$ & $27.38^{\mathrm{a}, \mathrm{B}} \pm 6.82$ \\
\hline \multicolumn{4}{c}{ a-b: significantly different in the same group $(\mathrm{p} \leq 0.05)}$. \\
& A-B: significantly different between groups $(\mathrm{p} \leq 0.05)$. \\
& \multicolumn{3}{c}{ \pm Standard Deviation }
\end{tabular}

After $72 \mathrm{~h}$ of the broiler chicken slaughter time it was found that SF values of PSE meat samples were higher than the control samples $(p \leq 0.05)$ while in the control samples, SF was not affected during storage although significant changes were observed in PSE fillets meat samples ( $p \leq 0.05)$. In PSE meat samples, there was a gradual increase of shear force values during storage occurring 2.5 -folder after $120 \mathrm{~h}$ post mortem in relation to $24 \mathrm{~h}$ and approximately 2 -folder than the control samples $(p \leq 0.01)$ (Table 3$)$. After $120 \mathrm{~h}$, the texture was not affected during storage under refrigeration. One explanation for these results lies on the excessive water loss during storage leading to the protein aggregation as observed in cooking loss of PSE meat at $120 \mathrm{~h}$ post mortem (Table 2). In addition, some authors have reported that inactivation of calpains was due to its early autolysis [3,5], which probably contributed to the increase of shear force $120 \mathrm{~h}$ post mortem value (Table 3).

\section{Myofibrillar Fragmentation Index (MFI)}

Table 4 shows the results of MFI evaluation for control and PSE broiler breast meat samples stored at $0 \pm 1^{\circ} \mathrm{C}$ for $120 \mathrm{~h}$. There was no significant difference $(p \geq 0.05)$ for MFI in sample kept for $24 \mathrm{~h}$ between both samples. PSE meat samples did not change significantly in the MFI values during storage, however from $72 \mathrm{~h}$ post mortem onwards the MFI of PSE meat was higher $(p \leq 0.05)$ than control group probably due to earlier activation of calpain. Increased protease activity in PSE samples was due to the higher concentration of intracellular $\mathrm{Ca}^{2+}$. This higher ion concentration should primarily enhance the $\mu$-calpain activity when, according to Lee et al. [1], the activity of this enzyme ceases due to autolysis.

Table 4 Myofibrillar Fragmentation Index (MFI) of control and PSE (Pale, Soft, Exudative) samples of broiler breast stored at $0 \pm 1 \stackrel{\circ}{\circ}$ for 24,72 and 120 hours post mortem.

Groups

\section{Myofibrillar Fragmentation Index}

\begin{tabular}{cccc} 
& $\mathbf{2 4} \mathbf{h}(\mathbf{n}=\mathbf{1 2})$ & $\mathbf{7 2} \mathbf{h}(\mathbf{n}=\mathbf{1 2})$ & $\mathbf{1 2 0} \mathbf{h}(\mathbf{n}=\mathbf{1 2})$ \\
\hline PSE meat & $81.31^{\mathrm{a}, \mathrm{A}} \pm 8.06$ & $76.79^{\mathrm{a}, \mathrm{A}} \pm 3.32$ & $77.06^{\mathrm{a}, \mathrm{A}} \pm 3.56$ \\
Control meat & $79.19^{\mathrm{a}, \mathrm{A}} \pm 3.43$ & $73.78^{\mathrm{b}, \mathrm{B}} \pm 2.43$ & $73.18^{\mathrm{b}, \mathrm{B}} \pm 1.82$ \\
\hline \multicolumn{4}{c}{ a-b: significantly different in the same group $(\mathrm{p} \leq 0.05)}$. \\
& $\mathrm{A}-\mathrm{B}:$ significantly different between groups $(\mathrm{p} \leq 0.05)$. \\
\multicolumn{3}{c}{ \pm Standard Deviation }
\end{tabular}

Wilhelm et al. [3] found a higher MFI values in PSE meat samples. These authors observed that after $72 \mathrm{~h}$ post mortem the ultrastructure of the fillets from PSE meat was more fragmented than the control samples, indicating higher proteolytic activities, similar to the results reported herein. Santos et al. [15] noted that in acute stressed chicken, MFI changed, although these results were not enough to influence SF values.

\section{Cathepsin Activities}

At $4 \mathrm{~h}$ post mortem, only cathepsins $\mathrm{L}$ and $\mathrm{H}$ activities were higher in the control group (Table 4). However, at $24 \mathrm{~h}$ post mortem, control samples had a marked decline in cathepsins $B+L$ and $L$ activities, whereas PSE meat samples had no significant changes in 
cathepsin activity, which demonstrates that these proteases have a prolonged action in PSE fillets. In the $24 \mathrm{~h}$ post mortem period, cathepsins $B+L$ and $L$ activities in PSE fillets were 28 $\%$ and $30 \%$ higher than those of control fillets, respectively. These isoforms remain active in PSE meat probably because of its low pH (5.64) compared to that of control fillets (5.98). As cathepsins $B$ and $L$ exhibit optimal activities at approximately pH 5.5 [9,27], PSE samples offered better conditions for the prolonged action of these enzymes.

Table 5 Cathepsin activities of control and PSE (Pale, Soft, Exudative) samples of broiler breast stored at $0 \pm 1 \stackrel{\circ}{ } \mathrm{C}$ for 4,24 and 72 hours post mortem.

PSE meat Control meat

\begin{tabular}{|c|c|c|}
\hline post mortem & \multicolumn{2}{|c|}{ B + L Cathepsins (FU) ${ }^{\star}$} \\
\hline $4 h(n=10)$ & $869.29^{a, A}$ & $935.31^{\mathrm{a}, \mathrm{A}}$ \\
\hline $24 \mathrm{~h}(\mathrm{n}=10)$ & $770.03^{\mathrm{a}, \mathrm{A}}$ & $551.21^{\mathrm{b}, \mathrm{B}}$ \\
\hline \multirow[t]{2}{*}{$72 \mathrm{~h}(\mathrm{n}=10)$} & $582.67^{\mathrm{a}, \mathrm{B}}$ & $585.68^{a, B}$ \\
\hline & \multicolumn{2}{|c|}{ B Cathepsins (FU)* } \\
\hline $4 \mathrm{~h}(\mathrm{n}=10)$ & $132.03^{\mathrm{a}, \mathrm{A}}$ & $137.17^{\mathrm{a}, \mathrm{A}}$ \\
\hline $24 h(n=10)$ & $115.07^{\mathrm{a}, \mathrm{A}}$ & $115.56^{\mathrm{a}, \mathrm{A}}$ \\
\hline \multirow[t]{2}{*}{$72 \mathrm{~h}(\mathrm{n}=10)$} & $133.59^{\mathrm{a}, \mathrm{A}}$ & $140.05^{\mathrm{a}, \mathrm{A}}$ \\
\hline & \multicolumn{2}{|c|}{ L Cathepsins (FU)* } \\
\hline $4 \mathrm{~h}(\mathrm{n}=10)$ & $732.26^{\mathrm{b}, \mathrm{A}}$ & $798.14^{\mathrm{a}, \mathrm{A}}$ \\
\hline $24 h(n=10)$ & $654.96^{\mathrm{a}, \mathrm{A}}$ & $435.65^{\mathrm{b}, \mathrm{B}}$ \\
\hline \multirow[t]{2}{*}{$72 h(n=10)$} & $449.08^{\mathrm{a}, \mathrm{B}}$ & $445.62^{\mathrm{aB}}$ \\
\hline & \multicolumn{2}{|c|}{ H Cathepsins (FU)* } \\
\hline $4 h(n=10)$ & $113.19^{b, A}$ & $147.03^{\mathrm{a}, \mathrm{A}}$ \\
\hline $24 \mathrm{~h}(\mathrm{n}=10)$ & $140.27^{\mathrm{a}, \mathrm{A}}$ & $136.74^{\mathrm{a}, \mathrm{A}}$ \\
\hline $72 \mathrm{~h}(\mathrm{n}=10)$ & $125.57^{\mathrm{a}, \mathrm{B}}$ & $141.14^{\mathrm{a}, \mathrm{A}}$ \\
\hline
\end{tabular}

${ }^{*}$ FU: Fluorescence unit.

$a-b$ : significantly different between groups $(p \leq 0.05)$.

A-B: significantly different in the same groups $(p \leq 0.05)$.

\section{Collagen Content}

Collagen content in PSE meat was $14.6 \%$ lower $(p \leq 0.05)$ than in control group at $24 \mathrm{~h}$ post mortem (Table 6 ). This result was probably related to the accelerated decline in $\mathrm{pH}$ values while the carcass temperature was still warm and under these conditions would lead to lysosomes rupture thus liberating cathepsins, which in turn acted enzymatically on the collagen molecules [26]. B and $L$ were probably the cathepsin components as they present an activity of $\mathrm{pH}$ optimum about 5.5 [9,27], as observed in our study (Table 5). Other reports have shown that these isoforms enzymes may affect the collagen molecules in its native form inducing the fibers cross-linking depolymerization $[9,27]$. Considering that $\mathrm{pH}_{3 \mathrm{~h}}$ value of the PSE meat samples was 5.64 and this fact might have contributed to the these enzymes digestion on collagen fibers. Although the mechanism of cathepsins over collagen is as yet not well understood. Kirschke et al. [27] suggested that these proteases act mainly on the collagen telopeptides digesting the crosslinkages regions. Based on studies with differential scanning calorimetry, Beltrán et al. [28] concluded that bacterial collagenase and cathepsin $B$ have similar mechanisms acting on the insoluble collagen. 
Table 6 Total collagen content of control and PSE (Pale, Soft, Exudative) samples of broiler breast stored at $0 \pm 1 \stackrel{\circ}{ } \mathrm{C}$ for 24,72 and 120 hours post mortem.

Groups

Total Collagen $(\mathrm{g} / \mathbf{1 0 0 g})$

$24 \mathrm{~h}$

\begin{tabular}{cccc} 
& $\mathbf{2 4} \mathbf{h}$ & $\mathbf{7 2} \mathbf{~ h}$ & $\mathbf{1 2 0} \mathbf{h}$ \\
\hline PSE meat & $0.35^{\mathrm{b}, \mathrm{B}} \pm 0.04$ & $0.38^{\mathrm{ab}, \mathrm{A}} \pm 0.04$ & $0.40^{\mathrm{a}, \mathrm{A}} \pm 0.02$ \\
Control meat & $0.41^{\mathrm{a}, \mathrm{A}} \pm 0.03$ & $0.36^{\mathrm{a}, \mathrm{A}} \pm 0.05$ & $0.36^{\mathrm{a}, \mathrm{A}} \pm 0.04$ \\
\hline \multicolumn{4}{c}{ a-b: significantly different in the same group $(\mathrm{p} \leq 0.05)}$. \\
& A-B: significantly different between groups $(\mathrm{p} \leq 0.05)$. & \\
& \multicolumn{3}{c}{ \pm Standard Deviation }
\end{tabular}

In addition to the probable role of calpain, the lower collagen content in PSE meat probably contributes to the lowest shear force observed in this $24 \mathrm{~h}$ post mortem meat samples. Furthermore, the soluble collagen content of PSE meat was about $25 \%$ higher ( $p \leq 0.05$ ) than the control samples $24 \mathrm{~h}$ post mortem (Table 7), collaborating with the tenderness of PSE meat. This fact suggested that cathepsins may also act earlier in PSE meat improving meat tenderness.

Table 7 Soluble collagen content of control and PSE (Pale, Soft, Exudative) samples of broiler breast stored at $0 \pm 1 \stackrel{\circ}{ } \mathrm{C}$ for 24,72 and 120 hours post mortem.

Groups

Soluble Collagen $(g / 100 g)$

$24 \mathrm{~h}$

\begin{tabular}{ccc} 
PSE meat & $0.12^{\mathrm{a}, \mathrm{A}} \pm 0.02$ & $0.13^{\mathrm{a}, \mathrm{A}} \pm 0.02$ \\
Control meat & $0.09^{\mathrm{b}, \mathrm{B}} \pm 0.02$ & $0.14^{\mathrm{a}, \mathrm{A}} \pm 0.04$ \\
\hline & $\mathrm{a}-\mathrm{b}:$ significantly different in the same group $(\mathrm{p} \leq 0.05)$ \\
& $\mathrm{A}-\mathrm{B}:$ significantly different between groups $(\mathrm{p} \leq 0.05)$ \\
& \multicolumn{2}{c}{ \pm Standard Deviation }
\end{tabular}

At 72 and $120 \mathrm{~h}$ post mortem, the collagen content of fillets was similar $(p \geq 0.05)$ in both control and PSE meat samples (Table 7). The soluble collagen (SC) content increased in the control samples, similarly to the PSE meat kept for $72 \mathrm{~h}$ post mortem (Table 6). Histochemical studies in beef samples have shown that in refrigerated stored meat a progressive rupture of lysosomes happened and after 14 days of storage, its breakdown was almost completed [29]. Therefore, in our experiment, probably in the control meat sample, it may undergo a gradual rupture of lysosomes throughout the storage period thus releasing cathepsins. As the $\mathrm{pH}$ values of the fillets already were at in the ideal range of the enzymes activity thus there were suitable conditions for breaking down the collagen molecules and consequently promoting their degradation.

\section{Pearson Correlation}

Correlations between the different measurements, such as $\mathrm{pH}_{3 \mathrm{~h}}, \mathrm{pH}_{24 h}, \mathrm{~L}^{*}, \mathrm{SF}, \mathrm{CL}, \mathrm{TC}$, $\mathrm{MFI}$ and SC were evaluated. A significant negative Pearson correlation is observed between $\mathrm{pH}_{3 h}$ and $\mathrm{CL}(-0.76, \mathrm{p} \leq 0.01)$ and $\mathrm{L}^{*}(-0.83, \mathrm{p} \leq 0.01)$ indicating that, the lower the $\mathrm{pH}_{3 h}$, the higher was the impairment of the functional properties of the meat proteins. Similar behavior was also observed for $L^{*}$ values in relation to $C L(0.79, p \leq 0.01)$, suggesting that, as meat becomes paler, the $C L$ increases. MFI values correlated positively with $L^{*}(0.53, p \leq 0.05)$ and $C L(0.56, p \leq 0.01)$, indicating that a higher proteolysis was correlated with higher impairment of the functional properties of meat. $\mathrm{TC}$ content correlated with $\mathrm{pH}_{3 \mathrm{~h}}(0.64, \mathrm{p} \leq$ $0.01)$ and $\mathrm{pH}_{24 \mathrm{~h}}$ indicating that PSE meat influenced the collagen content reduction. 


\section{Histological Evaluation}

Longitudinal and transverse electron micrographs confirmed this premature accelerated degradation of PSE meat myofibril and connective tissue proteins, as fewer collagen fibres were observed in these sections at $24 \mathrm{~h}$ post mortem (Figs $1 \mathrm{~A}$ and $1 \mathrm{~B}$ ). This higher protease activity was noted by transmission micrograph observations (Figs $1 \mathrm{~A}-\mathrm{a},-\mathrm{b},-\mathrm{c}$ and $-\mathrm{d}$ for the normal samples and Figs $1 \mathrm{~A}-\mathrm{e},-\mathrm{f},-\mathrm{g}$ and $-\mathrm{h}$ for the PSE meat samples, taken at 3, 24, 72 and $120 \mathrm{~h}$ post mortem and refrigerated). As shown in Fig. 1A, striking differences were already apparent in the transmission micrographs at $3 \mathrm{~h}$ post mortem. In the normal samples (Fig. 1A-a), the sarcomere components possessed intact bands from I and $A$ (zone $H$ ) and lines $Z$ and $M$; the same finding was not observed for the PSE samples (Fig. 1A-e). The myofilament structure of the PSE meat was partially shrunken, and the $Z$ lines were beginning to be enzymatically digested (Fig. 1A-e, arrow). It appears that the calpain systems initiated their activity in the PSE samples significantly earlier than in the normal samples [3]. This observation can be explained by the increase in the concentration of $\mathrm{Ca}^{2+}$ in the PSE samples, which likely occurred even before slaughtering. This hypothesis was supported by consistently lower $\mathrm{pH}$ values with respect to the normal samples. In fact, the excess $\mathrm{Ca}^{2+}$ within the tissue at this stage activates the $\mu$-calpain activity prematurely in birds when compared with mammals [5]. In mammals, a certain amount of time is necessary to initiate the maturation assembly, presumably because the $\mathrm{Ca}^{2+}$ concentration is not sufficiently high to induce muscle catabolism [5]. There is a specific relationship between the initiation of the enzymatic activity and the animal species. After $24 \mathrm{~h}$ of ageing, the normal samples presented with some depolymerised myofilaments, and the $Z$ lines were starting to be enzymatically digested at some locations (Figs 1 A-c and - $d$ ). In the PSE meat samples, the sarcomere was more disorganized at $4 \mathrm{~h}$ post mortem, and some lacunas were evident within the bands, indicating protein fragmentation. In the PSE samples, the typical dark and light pattern was not evident, and the $Z$ lines appeared more pronounced and were followed by lacunas (Fig. 1A-e). Myosin filaments were predominant within the sarcomeres and even touched the $Z$ lines, as shown in Fig. 1A-e; actin filaments were seldom observed. Open spaces were also visible, and a super muscle contraction was evident. One of the most affected muscle cell regions was at the triad, which is where the $T$ tubules join the sarcoplasm reticulum at the transition between bands I and $A$. This is the region where $\mathrm{Ca}^{2+}$ is released and promotes super contraction, which draws some of the sarcomere components towards the Z-lines and makes them comparatively very dense. From 72 to 120 $h$, it was clear there was Z-line digestion within the normal samples because some of the components at the sarcomere began to fragment (Figs $1 \mathrm{~A}-\mathrm{C}$ and $-\mathrm{d}$ as indicated by the arrowhead). In the PSE meat samples, a more dramatic enzymatic reaction occurred, which was observed at the 72 and $120 \mathrm{~h}$ storage periods, when the meat structure was likely to be collapsed (Figs $1 \mathrm{~A}-\mathrm{g}$ and $-\mathrm{h}$ ). This enzymatic activity provided a lower availability of the myofibrillar protein, with the minimum quantities observed at the 72 to $120 \mathrm{~h}$ storage periods; approximately $18.0 \%$ of the protein was lost in the PSE meat samples (Table 4). A difference in MFI between the PSE and normal meats was also apparent; the PSE meat had significantly greater MFI (approximately $5 \%$ more), indicating higher protease activity (Table 4).

The transverse electron micrographs presented in Fig. 1B corroborated the previous results observed in longitudinal studies. A larger space was observed at the endomysial region, and fewer collagen fibres were distributed throughout the extracellular spaces (Figs $1 B-d,-e$ and $-f)$. This reduction was the result of lysozyme activity, as calpains are unlikely to display any activity towards connective tissue proteins [1]. Therefore, the candidates are cathepsin enzymes. In fact, under bird pre-slaughter management conditions, the meat suffers dramatic stress. Furthermore, the cathepsin system can be activated when lysosomes are degraded under a higher temperature and lower $\mathrm{pH}$, which liberates these enzymes from the organelles [26,28], presenting prolonged activity in PSE meat, as observed in Table 5. This occurrence was corroborated by the results shown in Table 7; the total collagen fractions were $14.6 \%$ lower in the PSE meat samples and, conversely, $25.0 \%$ 
higher in the $24 \mathrm{~h}$ post mortem soluble fractions. In fact, cathepsins $\mathrm{B}$ and $\mathrm{L}$ are optimally active towards collagen molecules between a pH of 5.5 to 6.0 , which favours cathepsinic activity [26]. Moreover, at the age of 42 days, a broiler chicken contains more soluble than insoluble collagen fibres because the mature collagen crosslinks and pyridinolines are beginning to be synthesized [2]. This finding is shown in Table 6, in which the total collagen was more concentrated in the polymerized form in the normal samples. Conversely, there was more soluble collagen in the PSE meat samples regardless of the ageing period (Table 7).
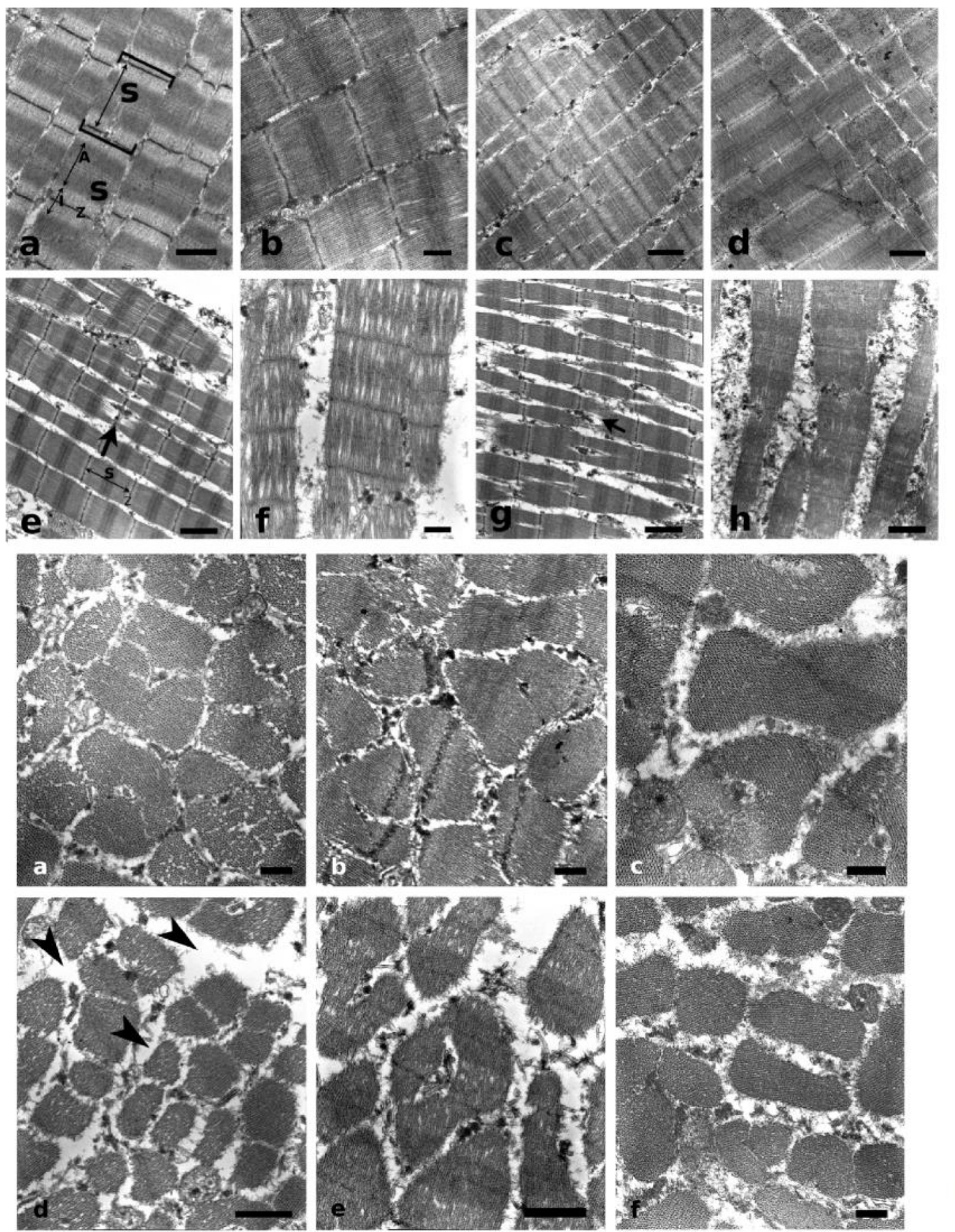

Figure 1 (A) Longitudinal electron micrograph of pectoralis major $\mathrm{m}$. from control group stored at $0 \pm 1$ ${ }^{\circ} \mathrm{C}$ for different times: a, b, c, d: control 4, 24, 72 e $120 \mathrm{~h}$ post mortem, respectively; e, f, g, h: PSE (Pale, Soft, Exudative) 4, 24, 72 e 120 h post mortem, respectively. s: sarcomere; a: a band; i: i band; $\mathbf{h}$ : $\mathbf{h}$ zone; $\mathbf{z}$ : $\mathbf{z}$ line. (bar $=1 \mu \mathrm{m}$ ). (b) electron micrograph of a transverse section of broiler pectoralis 
major $\mathrm{m}$. stored at $0 \pm 1 \stackrel{\circ}{\circ} \mathrm{C}$ for different times: $\mathbf{a}, \mathbf{b}, \mathbf{c}$ : control 4,24 e $120 \mathrm{~h}$ post mortem, respectively $(B a r=400 \mathrm{~nm})$; d, e, f: PSE 4, $24 \mathrm{E} 120 \mathrm{~h}$ post mortem, respectively. [Bar $=600 \mathrm{~nm}(\mathrm{~d}), 600 \mathrm{~nm}(\mathrm{e})$, $400 \mathrm{~nm}(\mathrm{f})]$.

\section{CONCLUSION}

PSE meat samples presented accelerated protein degradation in relation to the control samples due to the premature and prolonged proteases activity thus contributing initially to their relative higher tenderness. However, during ageing PSE meat showed higher Cooking Loss and Shear Force compromising its quality.

Funding: This research was funded by CNPq (National Council for Scientific and Technological Development), (Proc\# 475503/2009-0).

Acknowledgments: The author are thankful to CNPq. DFM was a graduate student under CAPES scholarchip. MS, FJH-B and Ell are CNPq Research Fellows.

Conflicts of Interest: The authors declare no conflict of interest.

\section{REFERENCES}

1. Lee HL, Santé-Lhoutellier V, Vigouroux S, Briand Y, Briand M. Role of calpains in post mortem proteolysis in chicken muscle. Poult Sci. 2008, 87, 2126-2132.

2. Coró FAG, Youssef EY, Shimokomaki M. Age related changes in poultry breast meat collagen pyridinoline and texture. J Food Biochem. 2002, 26, 533-541.

3. Wilhelm AE, Maganhini MB, Hernández-Blazquez FJ, Ida EI, Shimokomaki M. Protease activity and the ultrastructure of broiler chicken PSE (Pale, Soft, Exudative) meat. Food Chem. 2010, 119, 1201-1204.

4. Claeys E, De Smet S, Demeyer D, Geers R, Buys, N. Effect of rate of pH decline on muscle enzymes activities in two pig lines. Meat Sci. 2001, 57, 257-263.

5. Goll DE, Thompson VF, Li H, Wei W, Cong J. The Calpain System. Physiol Rev. 2003, 83, 731-801.

6. Bailey AJ. The role of collagen in the development of muscle and its relationship to eating quality. J Animal Sci. 1985, 60, 1580-1587.

7. Dutson TR. Ralationship of $\mathrm{pH}$ and temperature to disruption of specific muscle proteins and activity of lysossomal protease. J Food Biochem. 1983, 7, 223-230.

8. Sentandreu MA, Coulis G, Ouali A. Role of muscle endopeptidases and their inhibitors in meat tenderness. Trends Food Sci Technol. 2002, 13, 400-421.

9. Kirschke H, Barret AJ, Rawlings ND. Proteinases I: lysosomal cysteine proteinases. Protein Prof. 1995; 2, 1587-1620.

10. O'Halloran GR, Troy DJ, Buckley DJ, Reville WJ. The role of endogenous proteases in the tenderisation of fast glycolysing muscle. Meat Sci. 1997, 47, 187-210.

11. Hopkins DL, Thompson JM. The degradation of myofibrillar proteins in beef and lamb using denaturing electrophoresis - An overview. J Muscle Foods. 2002, 13, 81-102.

12. Soares AL, Ida El, Myiamoto S, Hernández-Blazquez FJ, Olivo R, Pinheiro J, Shimokomaki M. Phospholipase A2 activity in poultry PSE, pale, soft, exudative, meat. J Food Biochem. 2003, 27 , 309-320.

13. Li k, Zhao YY, Kang ZL, Wang P, Han MY, Xu XL, Zhou GH. Reduced functionality of PSE-like breast meat batter resulting from alteration in protein conformation. Poult Sci. 2015, 94, 111-122.

14. Zhao X, Bai $Y$, Xing T, Xu XL, Zhou G. Use of isoeletric solubilization/precipitacion process to modify the functional properties of PSE (Pale, Soft, Exudative)-like chicken meat protein: a mechanistic approach. Food Chem. 2018, 248, 201-209.

15. Santos CC, Delgado EF, Menten JFM, Pedreira ACM, Castilho CJC, Mourão GB, Brossi C, Silva IJO. Sarcoplasmatic and myofibrillar protein changes caused by acute heat stress in broiler chicken. Sci. Agric. 2008, 65, 453-458. 
16. Carvalho RH, Ida El, Madruga MS, Martínez SL, Shimokomaki M, Estévez M. Underlying connections between the redox system imbalance, protein oxidation and impaired quality traits in pale, soft and exudative (PSE) poultry meat. Food Chem. 2017, 215, 129-137.

17. Olivo R, Soares AL, Ida El, Shimokomaki M. Dietary vitamin E inhibits poultry PSE and improves meat functional properties. J Food Biochem. 2001, 25, 271-283.

18. Culler RD, Parrish FC, Smith GC, Cross HR. Relationship of myofibril fragmentation index to certain chemical, physical, and sensory characteristics of bovine longissimus muscle. J Food Sci. 1978, 43, 1177-1180.

19. Honikel KO. Reference methods for the assessment of physical characteristics of meat. Meat Sci. 1998, 49, 447-457.

20. Woessner JR. The determination of hidroxiproline in tissue and protein samples containing small proportions of this amino acid. Arch Biochem and Biophys. 1961, 93, 440-447.

21. Oliveira LB, Soares GJD, Antunes PL. Influência da maturação de carne bovina na solubilidade do colágeno e perdas de peso por cozimento. Rev Bras Agroc. 1998, 4, 166-171.

22. Guarnieri PD, Olivo R, Soares AL, Ida El, Lara JAF, Shimokomaki M. Preslaughter handling with water shower spray inhibits PSE (Pale, soft, exudative) broiler breast meat in a commercial plant. Biochemical and ultrastructural observations. J Food Biochem. 2004, 28, 269-277.

23. Karunanayaka DS, Jayasena DD, Jo C. Prevalence of pale, soft and exudative (PSE) condition in chicken meat used for comercial meat processing and its effect on roasted chicken breast. $J$ Anim Sci Technol. 2016, 58, 1-8.

24. Kissel C, Soares AL, Rossa A, Shimokomaki M. Functional properties of PSE (Pale, Soft, Exudative) broiler meat in the production of mortadella. Braz Arch Biol Technol. 2009, 52, 213-217.

25. Kato T, Barbosa CF, Ida EI, Soares AL, Shimokomaki M, Pedrão MR. Broiler chicken PSE (Pale, Soft, Exudative) meat and water release during chicken carcass thawing and Brazilian legislation. Braz Arch Biol Technol. 2013, 56(6), 996-1001.

26. Moeller PW, Field PA, Dutson TR, Landmann WA, Carpenter ZL. High temperature effects on lysosomal enzymes distribution and fragmentation of bovine muscle. J Food Sci. 1977, 42, 510-512.

27. Kirschke $H$, Kembhavi $A A$, Bohley $P$, Barrett $A J$. Action rat liver cathepsin $L$ on collagen and other substrates. Biochem J. 1982, 201, 367-374.

28. Beltrán JA, Bonnet $M$, Ouali $A$. Comparative action of cathepsin $B$ and $L$ on intramuscular collagen as assessed by differential scanning colorimetry. Meat Sci. 1992, 32, 299-306.

29. Zeece MG, Woods TL, Keen MA., Reville WJ. Role of proteinases and inhibitors in post mortem muscle protein degradation. In: Proc. of the Reciprocal Meat Conference; Colorado State University, Colorado, U.S.A; 1992, 51-61p.

(C) 2018 by the authors. Submitted for possible open access publication under the terms and conditions of the Creative Commons Attribution (CC BY NC) license (https://creativecommons.org/licenses/by-nc/4.0/). 